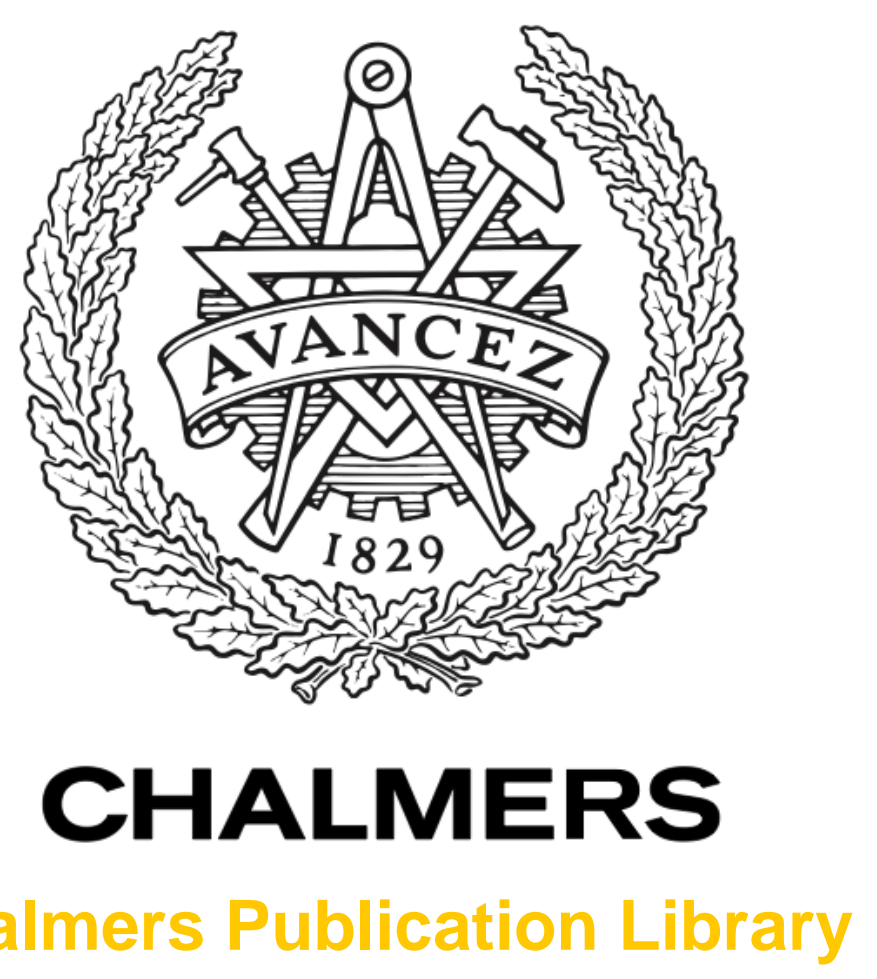

Challmers Publication Library

Factors for Eco-Efficiency Improvement of Thermal Insulation Materials

This document has been downloaded from Chalmers Publication Library (CPL). It is the author's version of a work that was accepted for publication in:

Key Engineering Materials (ISSN: 1013-9826)

Citation for the published paper:

Kono, J. ; Goto, Y. ; Ostermeyer, Y. et al. (2016) "Factors for Eco-Efficiency Improvement of Thermal Insulation Materials". Key Engineering Materials, vol. 678 pp. 1-13.

Downloaded from: http://publications.lib.chalmers.se/publication/225801

Notice: Changes introduced as a result of publishing processes such as copy-editing and formatting may not be reflected in this document. For a definitive version of this work, please refer to the published source. Please note that access to the published version might require a subscription.

Chalmers Publication Library (CPL) offers the possibility of retrieving research publications produced at Chalmers University of Technology. It covers all types of publications: articles, dissertations, licentiate theses, masters theses, conference papers, reports etc. Since 2006 it is the official tool for Chalmers official publication statistics. To ensure that Chalmers research results are disseminated as widely as possible, an Open Access Policy has been adopted.

The CPL service is administrated and maintained by Chalmers Library. 


\title{
Factors for Eco-efficiency Improvement of Thermal Insulation Materials
}

\author{
Jun Kono ${ }^{1 a}$, Yutaka Goto ${ }^{1}$, York Ostermeyer ${ }^{1}$, Rolf Frischknecht ${ }^{2}$, \\ Holger Wallbaum ${ }^{1}$ \\ 1 Chalmers University of Technology, Gothenburg, Sweden \\ 2 treeze Ltd., Zurich, Switzerland \\ a jun.kono@chalmers.se
}

\begin{abstract}
Keywords: Life Cycle Impact Assessment; LCIA; LCA; Cradle-to-Grave; Eco-efficiency; ISO 14045
\end{abstract}

\begin{abstract}
Thermal insulation material is an important component to reduce the environmental impact of buildings through the reduction of energy consumption in the operation phase. However, the material itself has embodied environmental impacts for the value it provides. Eco-efficiency is a method that quantifies relation between the environmental performance and the created value of a product system. This study investigated contributing factors of the eco-efficiency of thermal insulation materials to support decision making of material manufacturers. For the improvement of eco-efficiency, the assessment was made in two scopes: investigating the contributing factors of impact caused at production processes; and thermal performance through thermo-physical properties. For quantifying environmental impacts, cradle-to-grave life cycle assessment (LCA) of each materials were made. The life cycle impact assessment (LCIA) indicators used were ReCiPe H/A and global warming potential (GWP100a). For the assessment of production process, the inventories of the materials were assigned to six categories: heat, chemicals, electricity, transportation, raw materials and wastes. Among the assessed materials, contribution of electricity and heat within the production process was large for foam glass which had the highest potential to improve the eco-efficiency which was by factor 1.72. The analysis on relation between thermo-physical properties and eco-efficiency based on product data of the materials highlighted the importance of density as an indicator upon development and use. Although density often gains less attention, the finding suggested the effectiveness of improving the efficiency by having lower density without compensating the performance of the materials.
\end{abstract}

\section{Introduction}

The building sector plays an important role on global warming, contributing about $30-40 \%$ of anthropogenic greenhouse gas emission $[1,2]$. Most reports agree that there is significant potential for reducing greenhouse gas emission from improvements of the energy efficiency of the buildings [3-5]. Regarding the energy consumption of buildings, the requirements for heating, ventilation and air conditioning (HVAC) is a substantial contributors [6]. In fact, studies show that about half of their life cycle environmental impact is caused by the operation phase while impact caused during the production phase of materials are responsible for the remaining even for state-of-the-art energy efficient buildings [7-9]. For the reduction of such HVAC load, thermal insulation material plays a key role [10]. These insulation materials have been well utilized in some parts of the globe, though still underutilized in other readily applicable areas. According to IEA [5] many countries still construct new buildings without considering energy performance of the building envelopes, which unnecessarily increases the HVAC loads. As energy demands of the building sector are expected to increase worldwide due to an increase in office and dwelling space [5], thermal insulation materials must continue to play an important role as a key component in building envelopes to cope with the climate challenge.

Various research has been made on thermal insulation materials, which include the assessment of environmental impacts. The life cycle impact assessment (LCIA) on production of thermal insulation material has been conducted by Papadopoulos and Giama [11], and Pargana et al. [12]. Studies including end-of-life phase of the materials were made by Schmidt et al. [13], Dylewski and 
Adamczyk [14] where Dylewski and Adamczyk [14] included an economic perspective on the analysis that considered the payback time of several representative insulation materials. However, while the impact of the insulation material has been investigated and compared, the relation between the material properties and materials' environmental impact is less clear (e.g. the relation between the thermal conductivity and the embodied carbon of a material).

Eco-efficiency is a method which is standardized as ISO 14045 [15] that quantifies ratio of the created value and caused impact by product system over the life cycle. This method has been used in building projects such as [16] which used the space provision as the created value. As the method takes value criteria into account for assessing environmental impact of the product system, the present study looked into the contributing factors for eco-efficiency of the thermal insulation materials by investigating the inventories of production process and thermo-physical properties. The study also investigated the possible improvement potential for materials eco-efficiency. Through the analysis, the study aimed to highlight the factors for effective improvement of eco-efficiency.

\section{Methods}

Eco-efficiency of Thermal Insulation Materials and the Aim of the study. According to ISO 14045 [15], eco-efficiency of a product or service can be defined as an "aspect of sustainability relating the performance of product system to its product system value". The standard could thus be expressed as equation Eq. (1).

(eco-efficiency)

$$
=\frac{\text { (created value or fucntionality provided) }}{\text { (environmental impact) }}
$$

The defined eco-efficiency (EE) quantifies the amount of value created per the caused environmental impact. For the study, the created value was defined as thermal performance and the environmental impact as life cycle environmental impact of the material. For the thermal performance of the materials, thermal resistance was used which was set at $1\left[\mathrm{~m}^{2} \mathrm{~K} / \mathrm{W}\right]$ for surface area of $1\left[\mathrm{~m}^{2}\right]$ of thermal insulation materials. For the quantification of environmental impact, LCA was conducted. The aim of the LCA was to analyze key contributing factors for the eco-efficiency of thermal insulation materials and evaluate the effectiveness for the improvement on its EE.

In order to improve the defined EE in Eq. (1), two approaches could be determined: One is to reduce the environmental impact which can be achieved through the improvement in material's production process; the other is to improve the thermo-physical performance of the material. Therefore, the study investigated the factors for improving EE from the two approaches.

Quantification of Environmental Impact from Production Process. The analysis on production process was made by conducting a systematic assessment of materials' inventory, which was divided into six categories: energy input of heat, chemicals, energy input of electricity, transportation, raw materials and wastes. Every disposed inventories along the entire life cycle was categorized as wastes. For quantifying environmental impact, the LCA was conducted using a cradle-to-grave system boundary for each product. The functional unit of the study was set at the required mass for each material with identical thermal performance. This can be expressed as Eq. (2):

$$
\text { F.U. }=\lambda \cdot \rho \cdot \mathrm{R} \cdot \mathrm{A}
$$

where F.U. represents functional unit, $\lambda$ for thermal conductivity $[\mathrm{W} / \mathrm{mK}], \rho$ for density $\left[\mathrm{kg} / \mathrm{m}^{3}\right], \mathrm{R}$ for thermal resistance $\left[\mathrm{m}^{2} \mathrm{~K} / \mathrm{W}\right]$ and $\mathrm{A}$ for area $\left[\mathrm{m}^{2}\right]$ [17]. The performance was set at thermal resistance with $1\left[\mathrm{~m}^{2} \mathrm{~K} / \mathrm{W}\right]$ with surface area of $1\left[\mathrm{~m}^{2}\right]$ of the material.

In Fig. 1, the system boundary of the LCA and the scope for investigating improvement potential in production process is described: "Cradle to grave" as the system boundary; and "scope for optimization" as the scope. Within the scope, improvement potential was quantified through sensitivity analysis on inventories with significance based on contribution analysis. Note that the 
study had the focus on improvement within the given production process, thus any improvements of EE via reduction of the required energy or the change of raw materials was not considered.

The operation phase was considered that every material to last for 40 years without replacement or decay of the thermal performance. The material itself requires no energy consumption during its operation phase. For the disposal phase, it was assumed that mineral based materials are landfilled and the remaining ones are incinerated.

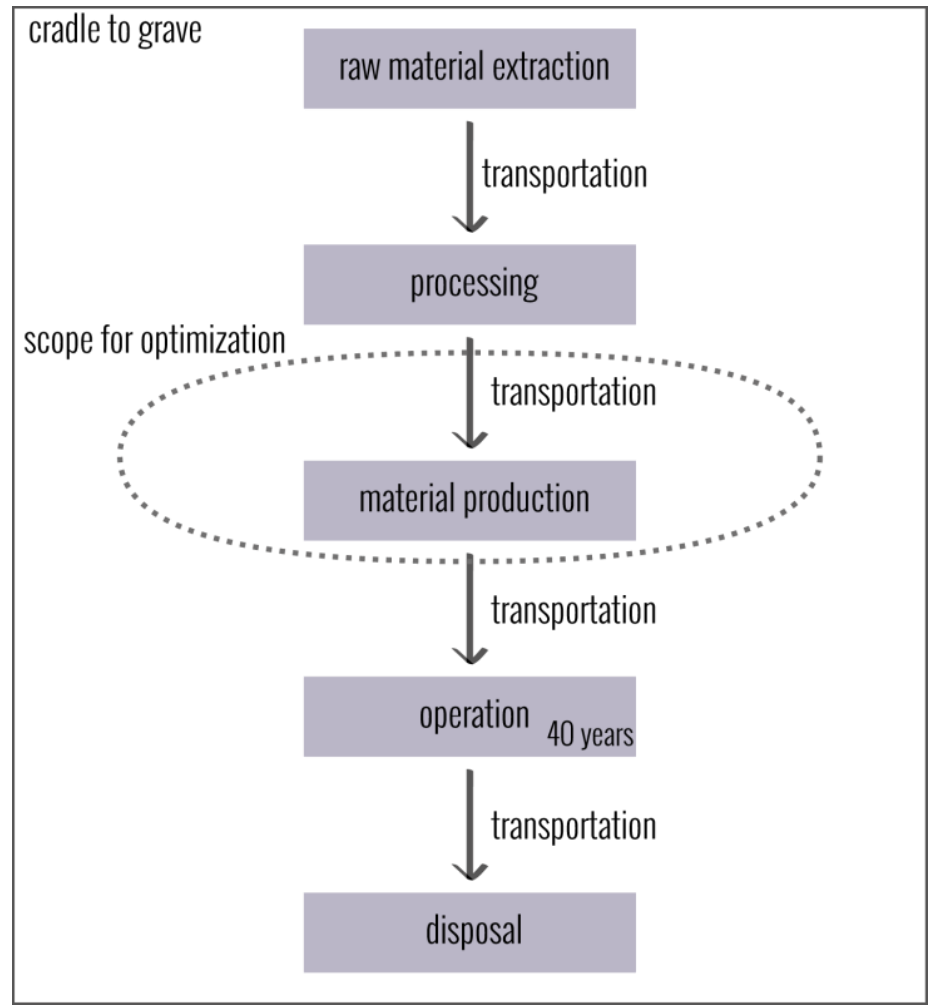

Fig. 1. Diagram of scope of the LCA on building thermal insulation material production

For the LCIA indicator, ReCiPe H/A (hereafter ReCiPe)[18] was selected to assess the production process as of its holistic coverage of the environmental impact, covering resource flows and emission flows[19]. In addition, GWP100a (hereafter GWP)[20], which covers the effect on single issue (global warming), was used for contribution analysis for comparison.

Even though ReCiPe has strong emphasis on fossil fuel depletion, it considers other issues including human toxicity, eco-toxicity and resource depletion. With its broader coverage of the environmental consequences, the EE for studying the production process adopted ReCiPe which is defined as Eq. (3).

$$
(\mathrm{EE})=\frac{\mathrm{R}}{(\mathrm{ReCiPe} \text { score })}
$$

The software in use to compute the environmental impact was SimaPro 8.04 [21].

Types of Thermal Insulation Materials and Inventory Data. The insulation materials studied for were selected by their market significance [22]. In Fig. 2, the market share of thermal insulation types in the seven largest markets are shown. The materials for investigating contribution factors for environmental performance from production process were selected based on current market share and future potential. In addition, materials were selected due to the availability of inventory data. The selected materials were: cellulose fibre, fibreboard, foam glass, stone wool, VIP and polyurethane (PUR). 


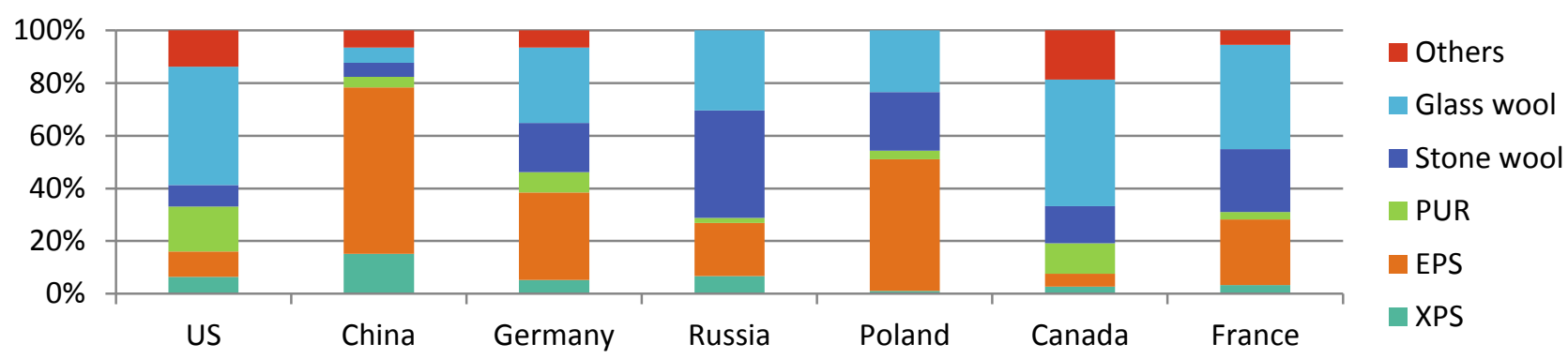

Fig. 2. Market share of 7 largest markets for thermal insulation materials

The main source of life cycle inventory data for analyzing the inventories was ecoinvent data v2.2 [23]. Life cycle inventory data of VIP referred to [24]. The properties and functional units used for LCA and data sources of the materials for investigating the improvement potential are shown in Table 1. All of these materials were considered to be applicable to various parts of buildings such as floors or roofs. For simplicity, the thermal conductivity does not take variance due to temperature or relative humidity of the surrounding environment into account.

Table 1: List of thermal insulation materials and its thermal conductivity and sources of inventory data

\begin{tabular}{|l|l|l|l|l|}
\hline Material & $\begin{array}{l}\text { Material } \\
\text { category }\end{array}$ & $\begin{array}{l}\text { Thermal conductivity } \\
{[\mathrm{W} / \mathrm{mK}]}\end{array}$ & $\begin{array}{l}\text { Density } \\
{\left[\mathrm{kg} / \mathrm{m}^{3}\right]}\end{array}$ & Inventory data source \\
\hline Cellulose fibre & Bio & 0.040 & 50 & {$[25]$} \\
\hline Fibreboard & Bio & 0.040 & 140 & {$[25]$} \\
\hline Foam glass & Mineral & 0.038 & 110 & {$[25]$} \\
\hline Stone wool & Mineral & 0.036 & 32 & {$[25]$} \\
\hline VIP & Other & 0.003 & 190 & {$[24]$} \\
\hline $\begin{array}{l}\text { Polyurethane } \\
\text { (PUR) }\end{array}$ & Polymer & 0.025 & 35 & {$[12,25]$} \\
\hline
\end{tabular}

As the study investigated the influence and feasible improvement on environmental impact of the production process, Table 2 briefly describes the process related to heating for each studied thermal insulation material.

Table 2: Required heating temperature during the production process of each thermal insulation material

\begin{tabular}{|l|l|l|l|}
\hline Material & $\begin{array}{l}\text { Required heating temperature for } \\
\text { production }\left[{ }^{\circ} \mathrm{C}\right]\end{array}$ & Purpose & Reference \\
\hline Cellulose fibre & none & none & {$[26]$} \\
\hline Fibreboard & $130-180$ & Pre-heating, flash drying & {$[11,26]$} \\
\hline Foam glass & $850-1250$ & Melting, foaming & {$[26]$} \\
\hline Stone wool & $1300-1650$ & Melting, strengthening & {$[11,26]$} \\
\hline VIP & N.A. & N.A. & {$[24]$} \\
\hline PUR & N.A. & N.A. & {$[27]$} \\
\hline
\end{tabular}

Analysis on Relevance of Thermal Performance on eco-efficiency. For improving the EE of thermal insulation materials, increasing the value created from the materials is another approach. By defining the created value as thermal performance of the material, which was set at thermal resistance with $1\left[\mathrm{~m}^{2} \mathrm{~K} / \mathrm{W}\right]$ of material in $1\left[\mathrm{~m}^{2}\right]$ for 40 years, thermal conductivity is typically gaining the focus for increasing the performance. However, when transforming Eq. (2),

$$
\mathrm{R}=\frac{\mathrm{F} \cdot \mathrm{U} \cdot}{\lambda \cdot \rho \cdot \mathrm{A}}
$$

density $(\rho)$ can also be seen as a property that interacts with the thermal resistance as shown in Eq. (4). Therefore, the study investigated the relevance of the two thermo-physical properties that defines 
the thermal performance of the material. The analysis on relevance of thermo-physical properties to EE were made based on existing product data.

In order to investigate the relation between the EE and the thermo-physical properties, the number of samples with adequate information was increased from inventory analysis. For this reason, the number of assessed material types (EPS and XPS) was increased. Moreover, data on environmental impact from other LCI databases such as, Inventory of Carbon \& Energy (ICE) version 2 [28] from the UK, Inventory Database for Lifecycle Analysis (IDEA) version 1.1.0 [29], and AIJ-LCA\&LCW [30] from Japan, have been investigated as reference despite the variation of the representativeness of data. For example the AIJ database relies on input-output based data, while others are average product data. Moreover, geological variation of the material dataset exists on every database.

In addition to LCI databases, product specific data from 23 Environment Product Declarations (EPD) were used. The list of EPD used is given in Table A in the Appendix. End of life phase of each dataset took scenarios from ecoinvent data which aligned the disposal scenario.

For the LCIA indicator, GWP was selected to assess the relation of the thermo-physical properties which allowed better access to data. Thus, the EE for the analysis on thermo-physical property was defined as Eq. (5):

$$
=\frac{\mathrm{R}}{(\mathrm{GWP})}
$$

\section{Results and Discussion on Eco-Efficiency of Insulation Materials}

In this section, the two approaches to improve the eco-efficiency of the thermal insulation materials were investigated, which were the reduction of environmental impact and the improvement on created value. First, the improvement potential on the production process were analyzed by conducting contribution analysis in two environmental indicators. The sensitivity analysis was made on inventory categories with significance to quantify the improvement potential in ReCiPe that covers more holistic environmental issues. This was followed by the analysis on the relevance of thermo-physical properties on eco-efficiency. Due to the availability of data, the analysis between thermo-physical properties and the efficiency was made by having GWP as the LCIA indicator.

Eco-efficiency and Production Process of Insulation Materials - Contribution of Electricity, Heat and Transportation on Environmental Impact. The result of contribution analysis on inventories of thermal insulation materials are shown in the following which the results in ReCiPe are given in Fig. 3 and emission of $\mathrm{CO}_{2}$ equivalent in GWP are given in Fig. 4.

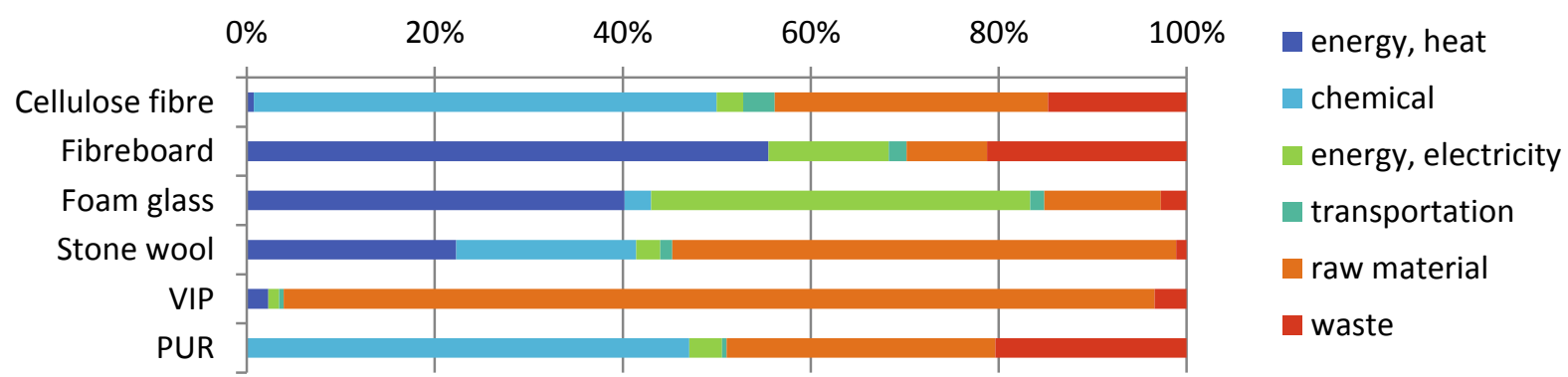

Fig. 3. Composition of raw material, transportation, energy on environmental impact of each thermal insulation material on $\mathrm{ReCiPe}$ in cradle-to-grave scope 


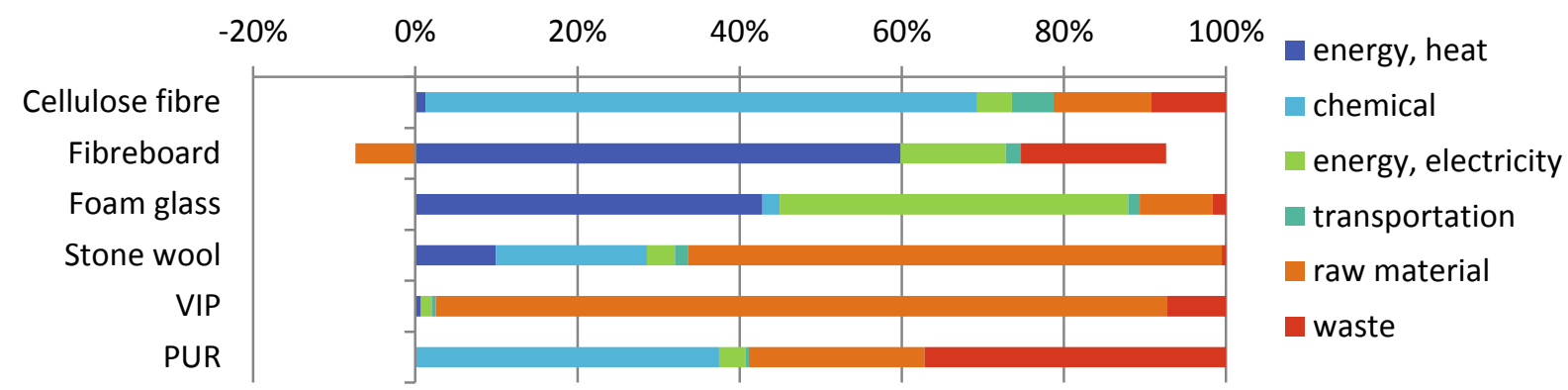

Fig. 4. Composition of raw material, transportation, energy on environmental impact of each thermal insulation material on GWP in cradle-to-grave scope

The obtained result shows significant variation of contributing categories among the investigated materials in both of the graphs. Meanwhile, the share of the inventory categories for each material between the two methodologies shows differences to a certain extent. For instance, cellulose fibre had larger impact from chemicals in GWP (62\%) than that of ReCiPe (49\%), while heat in stone wool had higher contribution in ReCiPe (22\%) than in GWP (10\%). The result illustrated the influence of the selected LCIA method, either with multiple or single issue being covered, for assessing the impact of the materials. However, the category of the most significant contribution remained the same on both methodologies for every material despite the difference in coverage.

As the study focuses on the improvement potential within the production process without intervening material properties, transportation, heat and electricity were focused. In

Table 3, the summary of the results from Fig. 3 on share of environmental impacts from electricity, heat and transportation is shown.

Table 3: Total contribution of electricity, heat and transportation of thermal insulation materials analyzed in ReCiPe and GWP in cradle-to-grave scope

\begin{tabular}{|l|l|l|l|l|l|l|l|l|l|l|l|l|}
\hline \multirow{2}{*}{ Unit: [\%] } & Cellulose fibre & \multicolumn{2}{l|}{ Fibreboard } & \multicolumn{2}{l|}{ Foam glass } & \multicolumn{2}{l|}{ Stone wool } & \multicolumn{2}{l|}{ VIP } & PUR \\
\cline { 2 - 14 } & ReCiPe & GWP & ReCiPe & GWP & ReCiPe & GWP & ReCiPe & GWP & ReCiPe & GWP & ReCiPe & GWP \\
\hline Electricity & 2.8 & 3.9 & 12.8 & 12.6 & 40.3 & 42.3 & 2.6 & 3.4 & 1.1 & 1.3 & 3.5 & 3.3 \\
\hline Heat & 0.8 & 1.2 & 55.5 & 58.0 & 40.2 & 42.1 & 22.3 & 9.9 & 2.3 & 0.7 & 0.0 & 0.0 \\
\hline Transport & 3.4 & 4.7 & 1.9 & 1.8 & 1.5 & 1.4 & 1.3 & 1.6 & 0.5 & 0.5 & 0.5 & 0.4 \\
\hline
\end{tabular}

From the result in

Table 3, the share of the transportation on the entire environmental impacts from material production can be concluded as marginal which limits the potential for improvement. On the other hand, certain share of impacts from electricity consumption can be seen for materials such as foam glass and fibreboard which were more than $40 \%$ and $12 \%$ respectively. Heat energy was also responsible for non-negligible share of impacts of fibreboard (over 55\%), foam glass (over 40\%) and stone wool (over 10\%) production. The fact indicates the improvement potential of EE for foam glass, fibreboard and stone wool by considering alternative heat sources.

Improvement of Eco-efficiency via Consumed Electricity. In order to decrease the impact caused from electricity consumption through average grid mix, changing the electricity source to renewable ones, such as PV or wind, may be one solution. As the purchasing of electricity generated from renewable energies are becoming available for manufacturers through products such as Renewable Energy Certificates (REC) or Renewable Energy Services (RES), case studies for improved EE by utilizing such products were made. In Fig. 5, different EE with four LCIA cases are shown, where all required electricity were supplied by average European grid (former Union for the Co-ordination of Transmission of Electricity (UCTE)), wind, photovoltaic and hydro power for defined functional unit of insulation materials. 


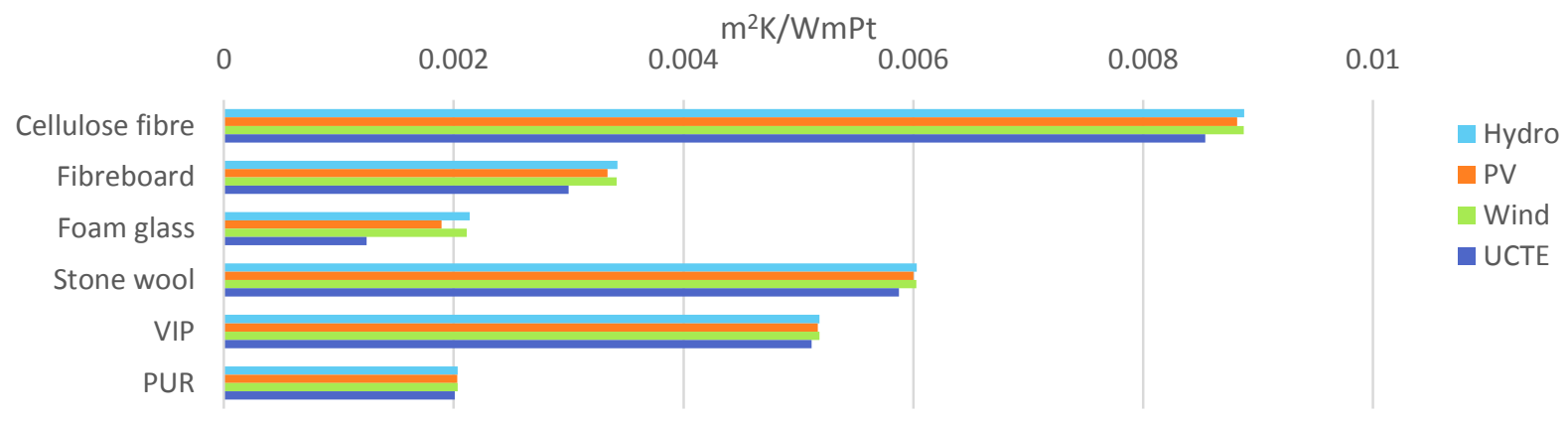

Fig. 5. Eco-efficiency of each case scenario on electricity consumed during the production process in $\mathrm{ReCiPe}$

As foam glass had high domination of impact from electricity consumption, it benefited the most from the option of purchasing electricity from renewable energies. For foam glass, the best scenario was when adopting hydro power which would allow the material to improve by factor 1.72 of its EE. In scenarios with purchasing electricity from wind and hydro energy, foam glass would outperform the environmental performance of PUR. Fibreboard also showed the potential to improve its efficiency by factor 1.14 .

Improvement of Eco-efficiency via Consumed Heat. As was shown in Fig. 3, products except cellulose fibre, VIP and PUR had large share of energy for heating on their environmental impacts. For fibreboards, wood chips may become an alternative heat source to improve the environmental performance of the product. Indeed, the heat is already partially supplied by them [25]. When calculating the case where the entire heat demand was met by wooden source, it allowed the material to improve its eco-efficiency by factor 1.27 using ReCiPe. This substitution of the heat source can be achieved thanks to the moderate temperature requirement, ranging around $150^{\circ} \mathrm{C}$, of the production process. However, the production of inorganic thermal insulation materials requires rather high temperatures which is over $1000^{\circ} \mathrm{C}$. In order to meet such heat demand with biomass, the required volume of the fuel will be large due to its relative low energy content against fossil fuels. Therefore, reduction of the impacts by changing the heating source for those products is expected to be rather limited from the economic viewpoint. Moreover, utilization of biomass as an energy source embeds risks of creating competitions on resource use for alternative purposes such as food supply, which is one of the common theme discussed for biofuels[31-33].

Relevance of Thermo-physical Properties to Eco-efficiency of the Material. As the increase of created value allows better eco-efficiency, this section investigated the relevance of two thermophysical properties and EE of thermal insulation materials to observe the tendency for effective approach to improve the efficiency. This was made by investigating the correlation between materials' $\mathrm{EE}$ and each of the thermo-physical properties from empirical data. Due to the availability of data, GWP was used as the only LCIA indicator for the environmental impact. In Fig. 6, correlation between the thermal conductivity and the EE, in Fig. 7, correlation between the density and the EE are shown. 

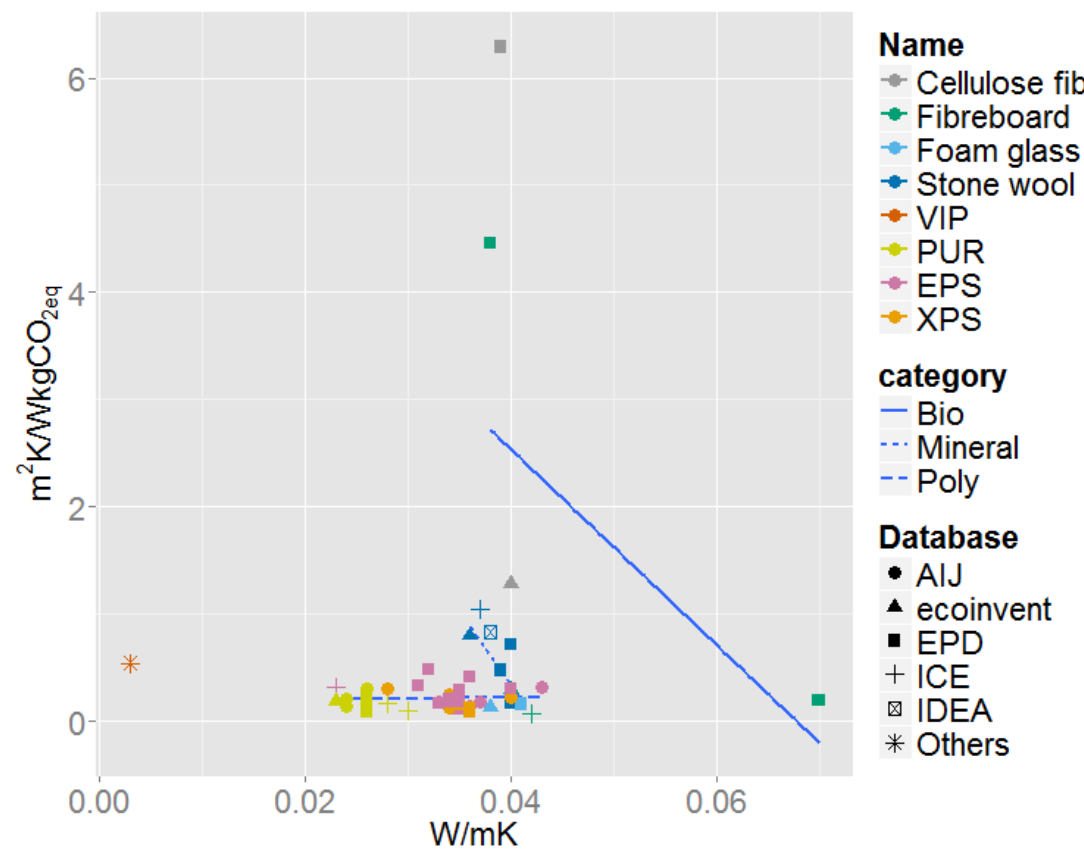

Fig. 6. Correlation between material thermal conductivity and eco-efficiency of materials in GWP from multiple data sources

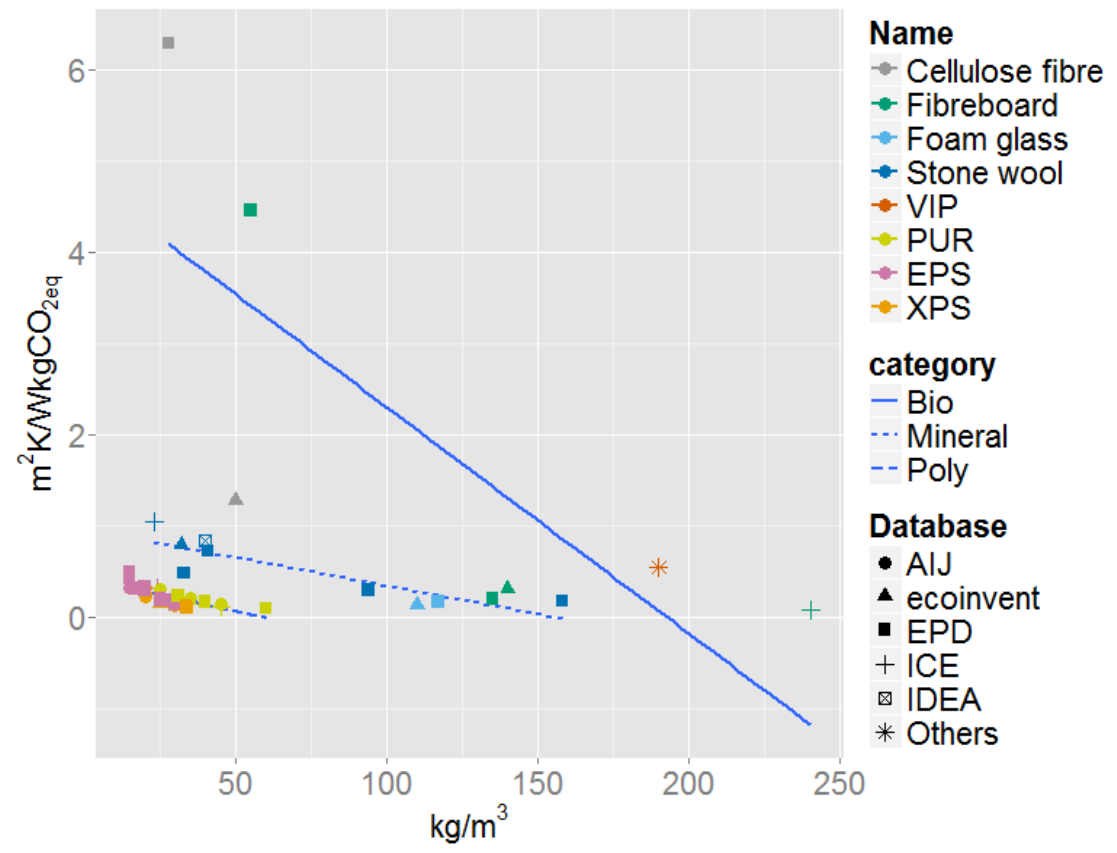

Fig. 7. Correlation between material density and eco-efficiency of materials in GWP from multiple data sources

By comparing Fig. 6 and Fig. 7, density showed clearer relation between the EE of thermal insulation materials than that of thermal conductivity. A general tendency observed from Fig. 7 was that the lower the density of a particular material is, the higher the EE are. In Table 4, the result of linear regression analysis of density and EE in Fig. 6 and Fig. 7 are shown. The obtained correlation coefficients confirmed the observed tendency, which were close to 0.80 in absolute value indicating high correlation for all material types. On the other hand, regression analysis of thermal conductivity and $\mathrm{EE}$ for each material category resulted with less correlation except mineral based materials with correlation coefficient with -0.60 . 
Table 4: Summary of linear regression analysis between thermo-physical properties and ecoefficiency of materials in GWP

\begin{tabular}{|l|l|l|l|l|}
\hline Material category & \multicolumn{2}{|l|}{ EE - thermal conductivity } & EE - density & \multicolumn{2}{l|}{$\begin{array}{l}\text { Correlation } \\
\text { coefficient }\end{array}$} \\
\cline { 2 - 5 } & Equation & $\begin{array}{l}\text { Correlation } \\
\text { coefficient }\end{array}$ & Equation & -0.75 \\
\hline $\begin{array}{l}\text { Bio (Cellulose fibre, } \\
\text { fibreboard) }\end{array}$ & $\mathrm{y}=-91.2 \mathrm{x}+6.2$ & -0.43 & $\mathrm{y}=-0.025 \mathrm{x}+4.781$ & -0.75 \\
\hline $\begin{array}{l}\text { Mineral (Foam glass, } \\
\text { Stone wool) }\end{array}$ & $\mathrm{y}=-134.8 \mathrm{x}+5.7$ & -0.64 & $\mathrm{y}=-0.006 \mathrm{x}+0.959$ & -0.88 \\
\hline $\begin{array}{l}\text { Polymer (PUR, EPS, } \\
\text { XPS) }\end{array}$ & $\mathrm{y}=1.08 \mathrm{x}+0.18$ & 0.06 & $\mathrm{y}=-0.007 \mathrm{x}+0.418$ & -0.74 \\
\hline
\end{tabular}

Today, lower thermal conductivity is the material property for thermal insulation materials that gains more attention in relation to environmental concerns among building designers upon selection. The same is true for the material manufacturers. However, the result illustrated the relevance and effectiveness of the development and use of materials with lower density that provides the same value it creates with better EE. Moreover, the fact suggests that achieving resource efficiency, which is one of the important environmental policy implemented currently in EU such as Roadmap to a ResourceEfficient Society [34], can promote materials with effective reduction of environmental impact per provided service.

Limitation of the Defined Eco-Efficiency of the Material. Another aspect related to a material's environmental impact and the thermal performance is on its service life. The service life determines the frequency of replacement and the maintenance of the material during its operation phase which was defined as 40 years with consistent thermal performance for the study. Among the data investigated in the study, there were variances of service life of materials. The range of service life stated in those documents is given in Table 5.

Table 5: Service life of insulation materials

\begin{tabular}{|l|l|l|}
\hline & Service life (years) & Reference \\
\hline Cellulose fibre & 50 & {$[35]$} \\
\hline Fibreboard & $50 /$ Building life time & {$[36,37]$} \\
\hline Foam glass & Unlimited & {$[38]$} \\
\hline Stone wool & Building life time / Unlimited & {$[39,40]$} \\
\hline VIP & 40 & {$[24]$} \\
\hline PUR & 50 & {$[41]$} \\
\hline EPS & $35-50$ & {$[42,43]$} \\
\hline XPS & Building life time & {$[44]$} \\
\hline
\end{tabular}

As it can be seen from Table 5, the service life of each material differed. When materials are implemented, the service life as described in the table may differ according to the surrounding environment of the buildings. Moreover, the length will be affected by the appropriateness of the implementation of the material. This appropriateness might be more of an issue for some materials. Furthermore, there is no standardized methodology to examine the service life or declaration of the decay of thermal performance over the operation phase of the material within EPD framework. As the defined EE took the thermal performance as the created value, the inclusion of performance decay will affect the EE of the materials. Therefore, illustrating the comparative advantage of EE between the materials that takes the environmental impact of full life cycle remains a challenge. 


\section{Conclusion and Outlook}

This study investigated the contributing factors of two approaches for improving eco-efficiency of thermal insulation materials: factors of production process and thermal performance. From the contribution analysis on production process which was made by categorizing the inventories into six, the improvement potential of the materials' impact was studied. Sensitivity analysis was made to elaborate potential influence on its impacts by changing electricity and heat sources. The relevance of thermo-physical properties on materials' eco-efficiency was investigated by analyzing existing product data that were accessible with adequate information.

For the improvement on production process, energy sources were key factors for some materials. Fibreboard was capable to obtain higher EE by factor 1.41 in total by fully utilizing renewable energy sources, both for heat and electricity. Foam glass also possessed the potential efficiency increase by factor 1.72. As other materials showed marginal potential for improvement, increasing the EE by improving the production process was less effective for those.

The analysis on thermo-physical properties of materials against its EE highlighted the role density can play for all types of thermal insulation materials. Even with the limitation on variation of data quality due to multiple sources, the result from regression analysis illustrated the importance of having a lower density of the material when determining its EE. The fact also suggested the effectiveness of resource efficiency policy for achieving reducing environmental impact without compensating the performance of the material.

Although having lower density may allow materials to have higher thermal performance per caused impact, there are other aspects that are related to materials. A material's strength is another important property which was not covered in the study. By taking such properties into account, which is one of engineering parameters, the importance of density may change. Further research opportunities can be seen for the inclusion of other material properties. Moreover, not just the created value but the caused environmental impact may also be expanded, such as assessing the impact on water use.

\section{Acknowledgement}

The author would like to thank EIT Climate KIC for funding the PhD studies for J. Kono and Chalmers Area of Advance Built Environment as well as Energy for their support of the interdisciplinary research at Chalmers.:

\section{Annex}

Table A shows the data used to create Fig. 6 and Fig. 7.

Table A: List of all inventories used for the analysis between eco-efficiency and thermo-physical properties

\begin{tabular}{|l|l|l|l|}
\hline Material & Thermal conductivity & Density & Reference \\
\hline PUR & 0.028 & 30 & {$[28]$} \\
\hline PUR & 0.03 & 45 & {$[28]$} \\
\hline Fibreboard & 0.042 & 240 & {$[28]$} \\
\hline Stone wool & 0.037 & 23 & {$[28]$} \\
\hline PUR & 0.023 & 24 & {$[28]$} \\
\hline Cellulose fibre & 0.04 & 50 & {$[25]$} \\
\hline Foam glass & 0.038 & 110 & {$[25]$} \\
\hline EPS & 0.035 & 30 & {$[25]$} \\
\hline XPS & 0.035 & 25 & {$[25]$} \\
\hline Stone wool & 0.036 & 32 & {$[25]$} \\
\hline Fibreboard & 0.04 & 140 & {$[25]$} \\
\hline VIP & 0.003 & 190 & {$[24]$} \\
\hline PUR & 0.023 & 35 & {$[25]$} \\
\hline
\end{tabular}




\begin{tabular}{|c|c|c|c|}
\hline Stone wool & 0.038 & 40 & [29] \\
\hline XPS & 0.034 & 30 & [30] \\
\hline stone wool & 0.046 & 25 & [30] \\
\hline stone wool & 0.051 & 35 & [30] \\
\hline stone wool & 0.036 & 40 & [30] \\
\hline EPS & 0.033 & 27 & [30] \\
\hline EPS & 0.036 & 30 & [30] \\
\hline EPS & 0.037 & 25 & [30] \\
\hline EPS & 0.04 & 20 & [30] \\
\hline EPS & 0.043 & 15 & [30] \\
\hline XPS & 0.04 & 20 & {$[30]$} \\
\hline XPS & 0.034 & 20 & {$[30]$} \\
\hline XPS & 0.028 & 20 & [30] \\
\hline PUR & 0.024 & 45 & [30] \\
\hline PUR & 0.024 & 35 & [30] \\
\hline PUR & 0.026 & 25 & [30] \\
\hline Cellulose fibre & 0.039 & 28 & [35] \\
\hline Fibreboard & 0.038 & 55 & [36] \\
\hline Fibreboard & 0.07 & 135 & [45] \\
\hline Foam glass & 0.041 & 117 & [38] \\
\hline Stone wool & 0.039 & 33 & [39] \\
\hline Stone wool & 0.04 & 158 & [40] \\
\hline Stone wool & 0.04 & 41 & [46] \\
\hline Stone wool & 0.04 & 94 & [47] \\
\hline PUR & 0.026 & 31 & [41] \\
\hline PUR & 0.026 & 40 & [48] \\
\hline PUR & 0.026 & 60 & [49] \\
\hline EPS & 0.035 & 20 & [50] \\
\hline EPS & 0.034 & 25 & [42] \\
\hline EPS & 0.033 & 30 & [51] \\
\hline EPS & 0.036 & 15 & [52] \\
\hline EPS & 0.034 & 25 & [53] \\
\hline EPS & 0.032 & 15 & [54] \\
\hline EPS & 0.031 & 20 & [55] \\
\hline EPS & 0.035 & 26.9 & [43] \\
\hline EPS & 0.04 & 17.5 & [43] \\
\hline XPS & 0.036 & 33.7 & [44] \\
\hline XPS & 0.036 & 34 & [56] \\
\hline XPS & 0.036 & 33.7 & [57] \\
\hline
\end{tabular}

\section{References}

[1] UNEP: Sustainable building and construction, (2003).

[2] IPCC: Climate Change 2014: Impacts, Adaptation, and Vulnerability. Part A: Global and Sectoral Aspects. Contribution of Working Group II to the Fifth Assessment Report of the Intergovernmental Panel on Climate Change, (2014).

[3] IEA: Energy performance certification of buildings: A policy tool to improve energy efficiency, International Energy Agencies, (2010).

[4] C. Petersdorff, T. Boermans, J. Harnisch: Environmental Science and Pollution Research 13 (2006) 350-358. 
[5] IEA: Technology Roadmap: Energy Efficient Building Envelopes, International Energy Agency, Paris, France, (2013).

[6] M.M. Koebel, A. Rigacci, P. Achard: in: M.A. Aegerter, N. Leventis, M.M. Koebel (Eds.), Aerogels Handbook, Springer New York, (2011), pp. 607-633.

[7] Y. Ostermeyer, H. Wallbaum, F. Reuter: The International Journal of Life Cycle Assessment 18 (2013) 1762-1779.

[8] M. Mosteiro-Romero, U. Krogmann, H. Wallbaum, Y. Ostermeyer, J.S. Senick, C.J. Andrews: Energy and Buildings 68 (2014) 620-631.

[9] G.A. Blengini, T.D. Carlo: The International Journal of Life Cycle Assessment 15 (2010) 14.

[10] M. Koebel, A. Rigacci, P. Achard: Journal of Sol-Gel Science and Technology 63 (2012) 25.

[11] A.M. Papadopoulos, E. Giama: Building and Environment 42 (2007) 10.

[12] N. Pargana, M.D. Pinheiro, J.D. Silvestre, J. de Brito: Energy and Buildings 82 (2014) 466-481.

[13] A.C. Schmidt, A.A. Jensen, A.U. Clausen, O. Kamstrup, D. Postlethwaite: The International Journal of Life Cycle Assessment 9 (2004) 14.

[14] R. Dylewski, J. Adamczyk: in: F. Pacheco-Torgal, L.F. Cabeza, J. Labrincha, A.G.d. Magalhaes (Eds.), Eco-Efficient Construction and Building Materials Life Cycle Assessment (LCA), EcoLabelling and Case Studies, (2014), pp. 267-286.

[15] International Organization for Standardization: ISO 14045:2012 Environmental management Eco-efficiency assessment of product systems -Principles, requirements and guidelines, Geneva, (2012).

[16] J. Teng, X. Wu: Ecological Indicators 39 (2014) 160-168.

[17] F. Ardente, M. Beccali, M. Cellura, M. Mistretta: Energy and Buildings 40 (2008) 1-10.

[18] M. Goedkoop, R. Heijungs, A.d. Schryver, J. Struijs, R.v. Zelm: ReCiPe 2008 - A life cycle impact assessment method which comprises harmonized category indicators at the midpoint and the endpoint level / Report I: Characterisation, Ministerie van VROM, Den Haag, Netherlands, (2009).

[19] S. Huysman, S. Sala, L. Mancini, F. Ardente, R.A.F. Alvarenga, S. De Meester, F. Mathieux, J. Dewulf: Resources, Conservation and Recycling 95 (2015) 68-76.

[20] IPCC: Climate Change 2007 : The Physical Science Basis: Working Group I Contribution to the Fourth Assessment Report of the IPCC, Cambridge University Press, (2007).

[21] PRé Consultants: SimaPro Version 8.04, The Netherlands, (2014).

[22] BASF, (2013).

[23] R. Frischknecht, et al.: The International Journal of Life Cycle Assessment 10 (2004) 3-9.

[24] U. Schonhardt, A. Binz, M. Wohler, R. Dott, R. Frischknecht: Ökobilanz eines VakuumIsolations-Paneels (VIP) (Life cycle assessment of a vacuum insulation panel (VIP)), Institut für Energie, Fachhochschule beider Basel, Muttenz (2003).

[25] ecoinvent Centre: ecoinvent data v2.0. ecoinvent reports No.1-25, Dübendorf, (2007).

[26] D. Kellenberger, H.-J. Althaus, T. Künniger, M. Lehman, N. Jungbluth, P. Thalmann: Life Cycle Inventories of Building Products. Final report ecoinvent Data v2.0 No.7, EMPA Dübendorf, Dübendorf, CH, (2007).

[27] R. Hischier: Life Cycle Inventories of Packagings \& Graphical Papers. ecoinvent report No.11, v2.0 EMPA Dübendorf, Dübendorf, Switzerland, (2007).

[28] G. Hammond, C. Jones: Inventory of Carbon \& Energy (ICE) Version 2.0, (2011).

[29] JEMAI: Inventory Database for Lifecycle Analysis (IDEA) version 1.1.0, (2012).

[30] AIJ: AIJ-LCA\&LCW ver.4.04, 5-26-20 Shiba, Minato-ku, Tokyo, Japan, (2006).

[31] A.P.C. Faaij: Energy Policy 34 (2006) 322-342.

[32] B. Hillring: Biomass and Bioenergy 30 (2006) 815-825.

[33] T. Myllyviita, A. Holma, R. Antikainen, K. Lähtinen, P. Leskinen: Journal of Cleaner Production 29-30 (2012) 238-245.

[34] European Commission: Communication from the Commission to the European Parliament, the Council, the European Economic and Social Committee and the Committee of the Regions. Roadmap to a Resource Efficient Europe COM(2011)571, Brussels, (2011). 
[35] ISOCELL GmbH: Blown insulation made of cellulose fibre, Bau EPD GmbH, Seidengasse 13/3, 1070 Wien, Austria, (2014).

[36] Kronoply GmbH: KRONOPLY flex (2014).

[37] GUTEX: Wood Fibre Insulating Boards (dry method), (2011).

[38] Pittsburgh Corning Europe NV: FOAMGLAS ® T4+, (2014).

[39] Knauf Insulation, d.o.o., Skofja Loka: DP-3 Multipurpose Rock Mineral Wool insulation, (2013).

[40] Deutsche ROCKWOOL Mineralwoll GmbH \& Co. OHG: Stone wool insulating materials in the high bulk density range (2012).

[41] PU Europe: PU thermal insulation board with mineral fleece facing (2014).

[42] EUEMPS: Expanded Polystyrene (EPS) Foam Insulation (shape moulded, density $25 \mathrm{~kg} / \mathrm{m}^{3}$ ) (2011).

[43] Industrieverband Hartschaum e.V.: EPS rigid foam (Styropor®) for ceilings/floors and as perimetric insulation, (2009).

[44] EXIBA - European Extruded Polystyrene Insulation Board Association: Extruded Polystyrene (XPS) Foam Insulation with HBCD flame retardant, (2014).

[45] Kronoply GmbH: KRONOTEX sound (2014).

[46] Deutsche ROCKWOOL Mineralwoll GmbH \& Co. OHG: Stone wool insulating materials in the low bulk density range (2012).

[47] Deutsche ROCKWOOL Mineralwoll GmbH \& Co. OHG: Stone wool insulating materials in the medium bulk density range (2012).

[48] PU Europe: Polyurethane thermal insulation spray foam (closed-cell; density $40 \mathrm{~kg} / \mathrm{m} 3$ ) (2014).

[49] PU Europe: Polyurethane thermal insulation spray foam (closed-cell; density $60 \mathrm{~kg} / \mathrm{m} 3$ ) (2014).

[50] EUEMPS: Expanded Polystyrene (EPS) Foam Insulation (density $20 \mathrm{~kg} / \mathrm{m}^{3}$ ) (2011).

[51] EUEMPS: Expanded Polystyrene (EPS) Foam Insulation (density $30 \mathrm{~kg} / \mathrm{m}^{3}$ ) (2011).

[52] EUEMPS: Expanded Polystyrene (EPS) Foam Insulation (density $15 \mathrm{~kg} / \mathrm{m}^{3}$ ) (2011).

[53] EUEMPS: Expanded Polystyrene (EPS) Foam Insulation (density $25 \mathrm{~kg} / \mathrm{m}^{3}$ ) (2011).

[54] EUEMPS: Expanded Polystyrene (EPS) Foam Insulation (with infra red absorbers, density 15 $\left.\mathrm{kg} / \mathrm{m}^{3}\right)(2011)$.

[55] EUEMPS: Expanded Polystyrene (EPS) Foam Insulation (with infra red absorbers, density 20 $\left.\mathrm{kg} / \mathrm{m}^{3}\right)(2011)$.

[56] FPX Fachvereinigung, Polystyrol-Extruderschaumstoff: XPS - Extruded Polystyrene Foam, (2010).

[57] EXIBA - European Extruded Polystyrene Insulation Board Association: Extruded Polystyrene (XPS) Foam Insulation with alternative flame retardant, (2014). 